\title{
PEMILIHAN RELAI PROTEKSI ANTI ISLANDING UNTUK PEMBANGKIT TERSEBAR
}

\author{
Adrianti \\ Jurusan Teknik Elektro, Fakultas Teknik, Universitas Andalas \\ e-mail: adrianti@ft.unand.ac.id
}

\begin{abstract}
Abstrak - Dalam aturan penyambungan pembangkit tersebar (PT) ke grid di berbagai negara, terdapat aturan bahwa jika grid terputus dari jaringan distribusi (islanding), PT harus segera diputuskan dari jaringan. Hal ini dilakukan untuk mencegah bahaya yang ditimbulkan oleh operasi islanding yang tidak direncanakan. Bahaya tersebut antara lain: peralatan proteksi yang ada akan gagal mendeteksi gangguan, penyambungan kembali grid tanpa sinkronisasi, bahaya tersengat listrik pada pekerja, serta tegangan dan frekuensi yang dihasilkan tidak terkontrol. Ada beberapa pilihan relai anti islanding yang dapat digunakan. Relai-relai anti islanding ini memiliki cara deteksi yang berbeda satu dengan lainnya, sehingga perlu dipilih metoda yang paling sesuai. Sensitivitas sebuah relai akan tergantung teknologi pembangkitan yang dimiliki oleh PT. Karena itu diusulkan sebuah metoda pemilihan relai anti islanding yang didasarkan tidak hanya dari teknologi pembangkitan yang digunakan, tapi juga kapasitas PT dan biaya yang harus dikeluarkan untuk pengadaan proteksi tersebut. Aplikasi metoda yang diusulkan pada kasus PT dengan teknologi generator sinkron menunjukkan bahwa metoda ini berhasil memilih peralatan yang sesuai, yaitu relai ROCOF. Walaupun pada awal analisa ada kekhawatiran relai ini tidak cukup sensitif akibat kedekatan keluaran PT dengan beban maksimum, namun dengan analisa yang lebih detail diperoleh relai ROCOF cocok untuk diaplikasikan.
\end{abstract}

\section{Kata Kunci : Proteksi anti islanding, Pembangkit tersebar dan ROCOF}

\begin{abstract}
Regulation of grid connected distributed generation (DG) in various countries states that in the event of disconnection of the grid, DG(s) must be disconnected from the distribution networks. This because an unplanned islanding can cause several hazard such as: failure of protection relays to detect faults, unsynchronized grid connection, electrocute risk for electrical workers and uncontrolled voltage and frequency in the network. There several anti-islanding protection with different detection methods that can be choose. Therefore, a suitable protection must be selected carefully. Sensitivity of anti-islanding relays are influenced by DG's generation technology. In this paper, a method to select an anti-islanding protection is proposed. The selection is based on DG's capacity, generating technology and cost. The proposed method has been applied to a case study of synchronous machine DG. At the beginning there is a doubt that a ROCOF protection may not be a suitable choice because DG's capacity quite closed to the maximum load in the network. But, after a rigorous analysis it shows that ROCOF protection can be applied to the DG with good sensitivity
\end{abstract}

Keywords : Anti-islanding protection, Distributed Generation and ROCOF

Copyright () 2017 JNTE. All rights reserved

\section{PENDAHULUAN}

Idealnya pembangkit tersebar (PT) dapat meningkatkan keandalan di sistem distribusi dengan memberikan suplai daya ke beban di jaringan distribusi saat gardu induk (grid) terputus. Grid umumnya terputus karena beroperasinya peralatan proteksi guna memutuskan gangguan. Tetapi kemampuan meningkatkan keandalan ini masih belum dapat dicapai karena operasi pembangkit tersebar saat grid terputus dapat menimbulkan masalah- masalah yang masih belum berhasil dicarikan solusinya. Masalah-masalah tersebut antara lain: dapat membahayakan pekerja jika mereka mengira jaringan distribusi tidak dialiri listrik, peralatan proteksi di jaringan distribusi tidak dirancang/disetting untuk kondisi grid terputus, sehingga ada kemungkinan gangguan yang terjadi tidak terdeteksi, ada kemungkinan terjadinya penyambungan grid kembali yang tidak disinkronisasi dengan PT, selain itu, tegangan dan frekuensi yang dihasilkan mungkin tidak berada dalam nilai yang diizinkan karena 
tidak ada grid yang mengontrol [1].

Untuk mencegah operasi PT saat kondisi grid terputus (yang dikenal juga dengan istilah islanding), maka saat grid terputus, PT harus dilepaskan dari jaringan distribusi. Di Indonesia, hal itu diatur dalam keputusan direksi PLN tentang Pedoman Penyambungan Pembangkit Listrik Energi Terbaharukan ke Sistem Distribusi PLN [2]. Dalam aturan tersebut, tidak disebutkan jenis peralatan/relai yang harus dipasang sebagai proteksi anti islanding. Hanya disebutkan bahwa dalam waktu 2 detik sejak grid terputus, PT harus sudah diputuskan dari jaringan.

Ada berbagai poteksi anti islanding yang tersedia. Karena itu, perlu dilakukan pemilihan peralatan proteksi anti islanding yang sesuai untuk PT yang akan dihubungkan ke jaringan PLN. Mengingat sensitivitas dan stabilitas suatu relai anti islanding sangat ditentukan oleh teknologi pembangkitan yang digunakan oleh PT, pemilihan jenis relai yang tepat menjadi penentu keberhasilan proteksi anti islanding [3].

Selain teknologi pembangkitan, hal lain yang juga berpengaruh terhadap pemilihan relai adalah biaya pengadaan dan pemasangan relai. Karena, menurut [2] penyediaan peralatan proteksi anti islanding ini dibebankan kepada pemilik PT. Jika kapasitas PT cukup kecil, pengadaan peralatan proteksi yang mahal tentu dipandang tidak ekonomis.

Dalam tulisan ini akan dibahas berbagai jenis relai anti islanding yang ada disertai prinsip kerjanya. Kemudian dilanjutkan dengan usulan metoda pemilihan relai yang sesuai dengan PT. Sebuah contoh aplikasi metoda untuk pemilihan relai diketengahkan. Tulisan diakhiri dengan kesimpulan dan saran.

\section{RELAI ANTI ISLANDING}

Teknologi yang digunakan untuk mendeteksi kondisi grid terputus secara garis besar dapat dibedakan atas 2 macam yaitu metoda yang memanfaatkan pengukuran lokal dan metoda yang membutuhkan komunikasi. Metoda yang memanfaatkan pengukuran lokal membuat keputusan trip atau tidak (grid terputus atau tidak) berdasarkan parameter yang diukur di dekat PT. Sedangkan metoda yang membutuhkan komunikasi membuat keputusan trip berdasarkan informasi yang dikirim dari grid [1].
Metoda yang menggunakan komunikasi biasanya lebih akurat dibandingkan metoda pengukuran lokal, tetapi biaya peralatannya lebih mahal. Jika kapasitas daya PT yang akan diproteksi cukup kecil, maka penggunaan metoda yang membutuhkan komunikasi menjadi tidak ekonomis.

Untuk meningkatkan keakuratan metoda yang memanfaatkan pengukuran lokal, dilakukan perbaikan dengan metoda aktif. Metoda aktif yaitu pengukuran lokal yang dilakukan setelah melakukan suatu aksi pada PT, misalnya dengan menaikkan atau menurunkan daya keluaran PT. Jadi metoda pengukuran lokal dapat diklasifikasikan atas dua metoda yaitu metoda pasif dan metoda aktif [1].

\subsection{Metoda Pasif}

Metoda pasif hanya memanfaatkan hasil pengukuran lokal di dekat PT untuk mendeteksi grid telah terlepas. Metoda pasif umumnya cocok digunakan untuk PT yang tidak dapat menghasilkan daya reaktif, yaitu pembangkit yang tidak menggunakan generator sinkron[4]. Dengan hilangnya sumber daya reaktif dari grid, kondisi islanding hanya akan berhasil bertahan jika PT dapat memberikan suplai daya reaktif. Akibatnya pada PT yang bukan bergenerator sinkron, akan terjadi penurunan tegangan dan juga frekuensi secara cepat. Penurunan ini akan dideteksi oleh relai under/over frekuensi dan (atau) relai under/over voltage sehingga PT akan dilepas dari sistem. Namun waktu yang diperlukan oleh relai frekuensi dan tegangan ini dapat lebih lama dari batasan 2 detik yang ditetapkan PLN, sehingga kadang diperlukan relai proteksi yang lebih cepat dan memang dirancang khusus untuk mendeteksi islanding. Relai-relai itu adalah sebagai berikut:

\section{ROCOF.}

ROCOF adalah singkatan dari Rate of Change of Frequency. Relai ROCOF bekerja jika perubahan frekuensi (df/dt) yang dirasakan lebih besar dari setting. Prinsip kerja relai ROCOF dapat dijelaskan dengan menggunakan Gambar 1. Saat jaringan distribusi terhubung ke grid, grid akan mengirim/menerima daya ke/dari jaringan distribusi tergantung perbandingan keluaran PT $\left(\mathrm{G}_{\mathrm{PT}}\right)$ dan konsumsi beban lokal (L). Jika Grid terputus karena beroperasinya CB, maka frekuensi di jaringan distribusi akan berubah. Perubahan frekuensi tergantung pada 
besar ketidakseimbangan antara daya yang dikeluarkan PT dan beban lokal saat grid terputus. Makin besar ketidakseimbangan makin besar perubahan frekuensi. Jika daya keluaran PT lebih besar dari beban lokal, maka frekuensi akan naik dan sebaliknya jika daya keluaran PT lebih kecil dari beban lokal, maka frekuensi akan turun.

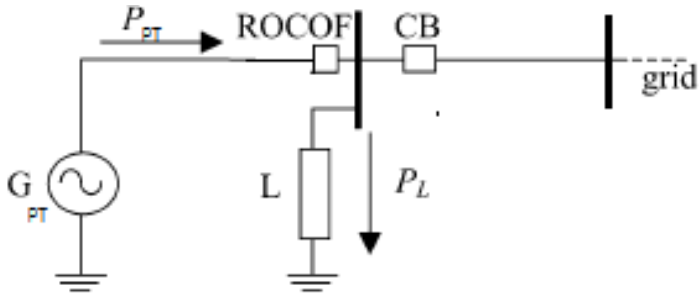

Gambar 1. Proteksi ROCOF

Permasalahan timbul jika keluaran PT sama dengan beban lokal saat grid terputus, sehingga tidak akan terjadi perubahan frekuensi dan relai ROCOF akan gagal mendeteksi terjadinya islanding. Demikian juga pada saat keluaran PT hanya sedikit berbeda dengan beban lokal dimana perubahan frekuensi yang terjadi lebih rendah dari setting relai ROCOF. Kondisi islanding yang tak terdeteksi ini disebut zona tak terdeteksi seperti yang diilustrasikan pada Gambar 2. Zona tak terdeteksi dapat diperkecil dengan cara menurunkan setting. Semakin kecil setting, semakin sempit zona islanding yang tak terdeteksi.

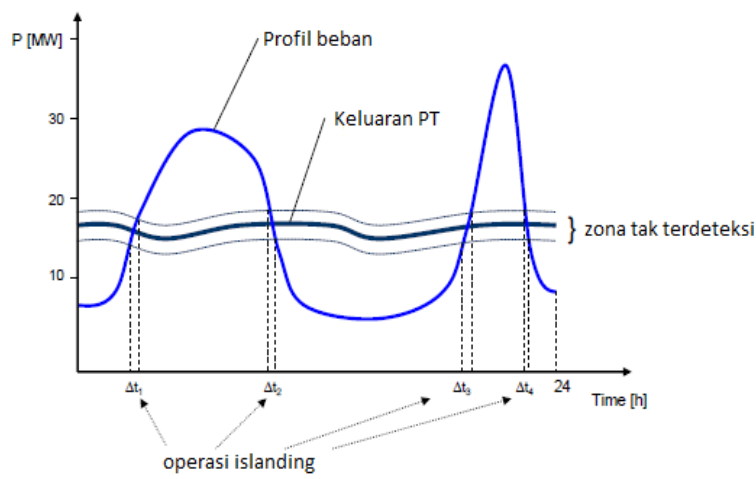

Gambar 2. Zona ROCOF gagal mendeteksi islanding [4]

Peningkatan sensitivitas relai ROCOF dengan membuat setting yang lebih rendah menimbulkan permasalahan stabiltas relai. Setting yang rendah membuat relai trip untuk berbagai perubahan frekuensi yang terjadi di sistem yang bukan merupakan kejadian islanding. Misalnya generator berkapasitas cukup besar terlepas dari sistem, sistem kehilangan beban atau gangguan hubung singkat di jaringan distribusi.

Karena itu diperlukan kompromi antara sensitivitas dan stabilitas relai ROCOF. Kompromi akan cenderung ke arah stabilitas jika kapasitas PT yang menggunakan relai ROCOF di sistem tenaga semakin signifikan. Misalnya, jika sebuah pembangkit terlepas, perubahan frekuensi yang dihasilkannya dapat memicu terlepasnya PT-PT yang ada di jaringan-jaringan distribusi sistem tersebut. Hal ini akan memperburuk kondisi kekurangan pembangkitan dan tentunya stabiltas sistem tenaga dan dapat memicu blackout. Mengingat pentingnya menjaga sekuriti sistem tenaga, maka relai ROCOF dibuat tidak terlalu sensitif. Seperti kondisi di Inggris, dimana setting relai ROCOF telah dinaikkan dari $0,125 \mathrm{~Hz} / \mathrm{s}$ menjadi $0,5-1 \mathrm{~Hz} / \mathrm{s}$ [5]

Ada berbagai measuring windows yang digunakan oleh relai ROCOF untuk menghitung perubahan frekuensi (df/dt), biasanya antara 2 cycles sampai 100 cycles [6]. Sebagai ilustrasi, perhitungan $\mathrm{df} / \mathrm{dt}$ untuk 3 cycles measuring windows adalah [4]:

$$
\frac{d f}{d t}=\frac{f_{n}-f_{n-3}}{t_{3 \text { cycles }}}
$$

Dimana:

$f_{n} \quad=$ frekuensi saat cycle $\mathrm{ke} \mathrm{n}(\mathrm{Hz})$

$f_{n-3} \quad=$ frekuensi saat cycle ke n-3

$t_{3 \text { cycles }}=$ waktu untuk 3 cycles (detik)

\section{Vector Shift}

Relai Vector Shift (VS) bekerja berdasarkan pergeseran fasa tegangan yang terjadi saat islanding. Penjelasan cara kerja relai VS diilustrasikan pada Gambar 3.

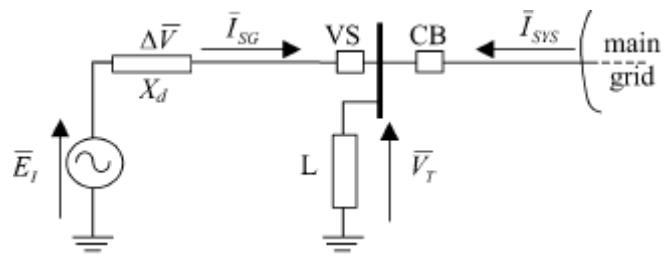

Gambar 3. Rangkaian ekivalen PT yang diproteksi dengan relai VS [7] 
Pada Gambar 3, sebuah PT melayani beban dan terhubung ke grid. Pada generator PT terjadi drop tegangan karena arus generator yang melewati $X_{d}$, reaktansi generator. Sehingga ada perubahan sudut $(\theta)$ antara tegangan internal generator $E_{i}$ dan tegangan terminal generator $V_{T}$, seperti yang ditunjukkan oleh Gambar 4a.

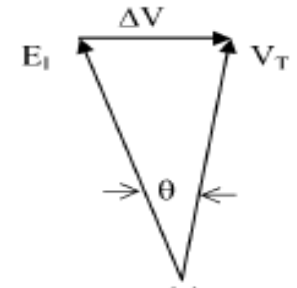

(a)

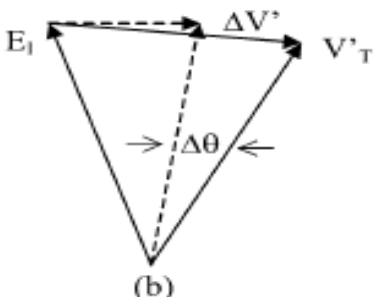

(b)
Gambar 4. Phasor tegangan internal dan terminal generator. (a). Sebelum grid terlepas. (b). Setelah grid terlepas [7]

Saat grid terlepas (kondisi islanding), PT akan menaikkan (menurunkan) daya keluaran untuk mengimbangi kebutuhan beban lokal, sehingga generator akan dipercepat atau diperlambat. Akibatnya beda sudut fasa $(\theta)$ akan diperbesar (diperkecil) karena perubahan arah dari tegangan terminal, seperti ditunjukkan pada Gambar 4.

Jika tegangan terminal generator terus diamati, maka akan diperoleh perubahan tegangan seperti yang ditunjukkan oleh Gambar 5. Titik A merupakan saat dimana terjadinya islanding. Setelah titik A, sudut fasa tegangan yang terjadi berubah sebesar $\Delta \theta$.

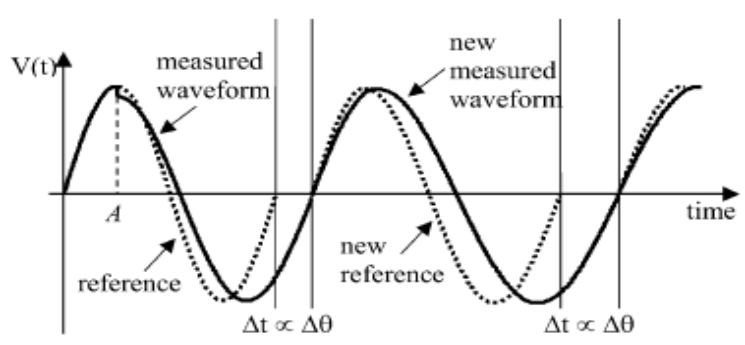

Gambar 5. Perubahan sudut fasa tegangan terminal generator PT $(\theta)$

Seiring dengan perubahan sudut fasa tegangan, waktu untuk satu cycle akan berubah dari waktu kondisi normal sebelumnya. Dengan membandingkan waktu untuk tiap cycle akan ekivalen dengan membandingkan sudut fasa tiap cycle. Saat terjadi islanding, waktu satu cycle dapat bertambah panjang atau bertambah pendek, sebanding dengan defisit atau kelebihan daya yang terjadi di jaringan.

Jika perubahan sudut yang terjadi lebih besar dari setting, maka relai VS akan trip. Tetapi berdasarkan penelitian di [4] relai VS tidak cukup sensitif untuk mendeteksi islanding jika PT menggunakan generator sinkron dengan ketidakseimbagan daya saat islanding $10 \%$ atau kurang. Untuk kondisi ini, relai ROCOF memiliki sensitifitas yang lebih baik.

\subsection{Metoda Aktif}

Metoda aktif untuk mendeteksi kodisi islanding dilakukan dengan cara memberikan gangguan (perturbation) atau perubahan ke jaringan distribusi secara periodik, kemudian memonitor efek yang dihasilkan. Jika saat itu grid terhubung maka tidak ada perubahan (frekuensi/tegangan) yang terjadi, karena efeknya diserap oleh sistem tenaga yang relatif besar dibandingkan gangguan yang diberikan. Akan tetapi jika grid telah terputus, maka akan ada perubahan pada parameter jaringan akibat gangguan (perturbation) yang diinjeksikan tersebut.

Metoda aktif dapat mengatasi masalah zona tak terdeteksi yang dialami metoda aktif. Akan tetapi metoda aktif dapat menimbulkan permasalahan kualitas listrik pada sistem. Metoda yang berdasarkan prinsip deteteksi aktif ini antara lain: inter harmonic injection, sandia voltage shift, change of output power periodically, automatic phase shift, sandia frequency shift, slip mode frequency shift dan impedance detection [1]. Metoda ini umumnya masih belum dalam bentuk relai yang tersedia di pasaran. Untuk mengatasi permasalahan kualitas listrik akibat injeksi secara periodic dari metoda aktif ini, beberapa penelitian menawarkan metoda hybrid, yaitu gabungan metoda pasif dan metoda aktif. Di saat metoda pasif berada pada zona tak terdeteksi, maka metoda aktif mulai bekerja dengan injeksinya [8].

\subsection{Metoda yang Memanfaatkan Komunikasi}

Dengan komunikasi, grid dapat mengirimkan informasi kejadian grid terputus kepada relai sehingga relai beroperasi untuk memutus PT dari jaringan. Metoda ini lebih baik sensitivitas dan stabilitasnya dari pada metoda lokal, tetapi butuh peralatan yang mahal. Metoda ini memanfaatkan saluran komunikasi seperti: 
kanal komunikasi yang disewa, gelombang radio atau microwave, power line carier atau kawat komunikasi [9].

\section{PENGARUH KAPASITAS DAN TEKNOLOGI PT DALAM PEMILIHAN PROTEKSI ANTI ISLANDING}

Hal yang paling menentukan pemilihan relai anti islanding adalah kapasitas PT. PT berkapasitas dibawah 200KVA biasanya akan sulit untuk mempertahankan operasi islanding karena kekurangan suplai daya untuk beban di jaringan. Sehingga untuk PT dengan kapasitas ini kondisi islanding akan langsung terdeteksi oleh relai under-frekuensi, relai under-voltage atau relai reverse power [9] yang ada di PT tersebut. Jadi tidak diperlukan relai khusus untuk mendeteksi terjadinya islanding.

Untuk PT yang kapasitasnya lebih dari 200 KVA, jenis proteksinya akan dipengaruhi oleh teknologi pembangkitan yang digunakan dan juga kemungkinan PT dapat melayani beban lokal (kapasitas PT cukup untuk melayani beban pada waktu tertentu).

\subsection{PT dengan Teknologi Generator Sinkron}

Generator sinkron umumnya digunakan pada PT hidro dan termal. Karena generator sinkron memiliki kemampuan untuk membangkitkan daya reaktif, sehingga kondisi islanding dapat bertahan selama daya keluaran PT cukup dekat dengan daya beban di jaringan. Karena itu dibutuhkan peralatan khusus untuk mendeteksi kondisi islanding. Berdasarkan uraian pada bagian 2, proteksi anti islanding yang paling sensitif dan stabil adalah yang memanfaatkan telekomunikasi. Akan tetapi biaya untuk proteksi ini sangat mahal dan hanya akan cukup ekonomis jika diterapkan pada PTPT yang berkapasitas besar. Untuk PT yang berkapasitas cukup kecil dapat dipilih metoda pasif ataupun metoda hybrid. Metoda hybrid menjanjikan performa yang lebih baik dari metoda pasif karena zona tak terdeteksinya dapat dibuat sangat kecil atau bahkan tidak ada. Akan tetapi metoda tersebut baru dalam taraf ide dan belum tersedia di pasaran. Di lapangan, sejauh ini relai anti islanding metoda pasif yang paling sensitif adalah relai ROCOF, walau ada permasalahan sensitivitasnya seperti yang dibahas pada bagian 2.1. a. Biasanya dengan menggunakan setting $0,4 \mathrm{~Hz} / \mathrm{s}$, relai ROCOF masih dapat mendeteksi islanding yang terjadi saat ketidakseimbangan daya PT dan beban minimum $10 \%$ [4].

\subsection{PT dengan Teknologi Doubly Fed Induction Machine \\ Doubly Fed Induction Generator atau} DFIG adalah jenis generator yang biasanya digunakan pada pembangkit listrik tenaga angin. Pada PT dengan generator ini, kondisi islanding akan mudah sekali terdeteksi karena islanding akan menyebabkan perubahan tegangan dan frekuensi yang sangat signifikan walaupun daya keluaran PT cukup dekat dengan beban di jaringan [4]. Sehingga, penambahan peralatan proteksi anti islanding sebenarnya tidak terlalu dibutuhkan karena relai under/over-voltage dan under/over frequency akan dengan mudah mendeteksi islanding dalam waktu kurang dari 2 detik.

\subsection{PT dengan Teknologi DC Inverter link}

Pada PT dengan teknologi DC Inverter, misalnya pada photovoltaic umumnya tidak dapat bertahan dalam kondisi islanding karena tidak adanya sumber daya reaktif yang dihasilkan pembangkit. Ketidakseimbangan daya reaktif antara PT ini dan beban di jaringan, memicu perubahan frekuensi yang lebih besar dari pada ketidakseimbangan daya aktif. Sehingga islanding akan lebih mudah terdeteksi. Untuk ketidakseimbangan daya reaktif sebesar 5\% antara pembangkitan dan beban saat islanding, setting maksimal relai ROCOF yang masih dapat mendeteksi islanding adalah $0,5 \mathrm{~Hz} / \mathrm{s}$, sedangkan untuk ketidakseimbangan daya aktif $5 \%$ adalah $0,3 \mathrm{~Hz} / \mathrm{s}$ untuk jenis relai ROCOF dari produsen tertentu [4].

\section{METODA PEMILIHAN RELAI ANTI ISLANDING}

Pada penelitian ini diusulkan suatu metoda (flowchart) yang dapat dipakai dalam pemilihan relai anti islanding yang paling sesuai dengan mempertimbangkan teknologi pembangkitan yang digunakan, daya keluaran PT dan kurva beban yang ada di jaringan distribusi. Kapasitas PT juga menjadi landasan pemilihan, karena untuk PT dengan kapasitas kecil, penggunaan relai yang mahal akan sulit direalisasikan karena pertimbangan ekonomi. Pemilihan didasarkan pada aturan PLN yang memberikan batas waktu 
2 detik setelah grid terputus, PT harus terlepas dari jaringan [2].

Metoda yang diusulkan dapat dilihat pada Gambar 6. Pada PT yang tidak menggunakan generator sinkron, kondisi islanding akan sulit bertahan karena tidak adanya daya reaktif yang dihasilkan pembangkit, sehingga penurunan tegangan dan frekuensi akan terjadi dan menyebabkan islanding lebih mudah dideteksi. Sehingga metoda pasif sudah memadai sebagai proteksi anti islanding. Bahkan khusus bagi PT dengan generator DFIG, tidak diperlukan proteksi khusus bagi anti islanding, karena relai over/under voltage dan over/under frekuensi yang ada di PT sudah memadai untuk mendeteksi kondisi islanding.

Untuk PT dengan generator sinkron, islanding akan dapat bertahan jika generator mampu melayani daya beban. Akibatnya pemilihan proteksi anti islanding menjadi lebih rumit. Metoda komunikasi merupakan metoda proteksi anti islanding yang paling sensitif dan stabil bagi PT bergenerator sinkron. Hambatan yang menghalangi penggunaan proteksi metoda komunikasi adalah biayanya yang tinggi. Sehingga, jika kapasitas PT tidak cukup besar, maka pembelian proteksi ini akan membuat PT tidak ekonomis. Sehingga metoda hybrid akan menjadi pilihan yang disarankan.

Pada flowchart ditunjukkan bahwa jika PT menggunakan generator sinkron akan dicek dengan blok pengambilan keputusan apakah PT dapat melayani beban lokal secara mandiri? Untuk menjawab pertanyaan tersebut perlu dilakukan analisa keseimbangan daya aktif dan reaktif beban terhadap keluaran PT seperti diilustrasikan pada Gambar 2. Umumnya, untuk perbedaan (ketidaksetimbangan) daya minimal $10 \%$, relai akan berhasil mendeteksi kondisi islanding. Untuk mengecek ketidakseimbangan keluaran PT terhadap beban sebesar $\pm 10 \%$, pada Gambar 2, diplot keluaran PT lebih besar 10\% atau lebih kecil 10\% dari kapasitas PT yang ditunjukkan oleh kurva di atas dan di bawah kurva keluaran PT. Lama waktu dimana relai tidak mendeteksi islanding (zona tak terdeteksi) ditunjukkan oleh $\Delta \mathrm{t}_{1}, \Delta \mathrm{t}_{2}, \Delta \mathrm{t}_{3}$ dan $\Delta \mathrm{t}_{4}$. Jika waktu operasi Circuit Breaker adalah 0,3 detik, dan PT harus sudah diputus dari jaringan dalam waktu 2 detik sejak grid terputus maka lama zona tak terdeteksi yang diizinkan adalah 1,7 detik. Sehingga jika zona tak terdeteksi lebih besar dari 1,7 detik, proteksi metoda pasif tersebut tidak memenuhi persyaratan waktu yang ditetapkan PLN.

Relai anti islanding metoda pasif yang disarankan pada flowchart hanya relai ROCOF. Karena relai ROCOF adalah relai metoda aktif yang paling sensitif yang tersedia di pasaran hingga saat ini [4].

\section{PENERAPAN METODA PEMILIHAN RELAI ANTI ISLANDING PADA PT.}

Metoda pemilihan relai anti islanding yang diusulkan diaplikasikan pada sebuah jaringan distribusi yang memiliki sebuah PT bergenerator sinkron yang datanya diambil dari [10]. Diagram satu garis sistem distribusi tersebut ditunjukkan pada Gambar 7.

Data beban maksimum dan kapasitas PT ditunjukkan pada Tabel 1. Terlihat bahwa daya aktif dan reaktif maksimum yang dibutuhkan beban di jaringan sedikit lebih tinggi dari daya aktif dan reaktif keluaran dari PT. Tetapi ada kemungkinan bahwa suatu waktu kebutuhan beban sama dengan keluaran PT. Saat keseimbangan daya inilah, relai metoda pasif akan gagal mendeteksi kondisi grid terputus. Karena itu, dibutuhkan informasi perubahan beban per jam yang biasanya diberikan oleh grafik kurva beban.

Tabel 1. Data daya beban maksimum dan daya keluaran PT

\begin{tabular}{|c|c|c|}
\hline Bus/Pembangkit & kW & kVar \\
\hline Bus 4 & 854.25 & 529.42 \\
\hline Bus 5 & 794.75 & 492.54 \\
\hline Bus 6 & 382.5 & 237.05 \\
\hline Bus 8 & 55.25 & 34.24 \\
\hline Total beban & 2086.75 & 1293.25 \\
\hline Keluaran PT & 1800 & 871.78 \\
\hline
\end{tabular}

Jika diasumsikan siklus turun naik beban di jaringan tersebut dengan mengambil pola kurva beban pada [11], maka variasi kebutuhan beban akan direpresentasikan oleh kurva berwarna biru pada gambar 8 . Kurva beban tersebut dibuat dengan cara menghitung persentase daya beban tiap jam terhadap beban puncak (beban maksimum) pada [11]. Persentase tersebut dikali dengan total beban maksimum di Tabel 1, dan digunakan untuk memplot kurva beban di sistem yang dianalisa. Pada Gambar 8 juga diplot kurva keluaran PT yang konstan sebesar $1800 \mathrm{KW}$. 


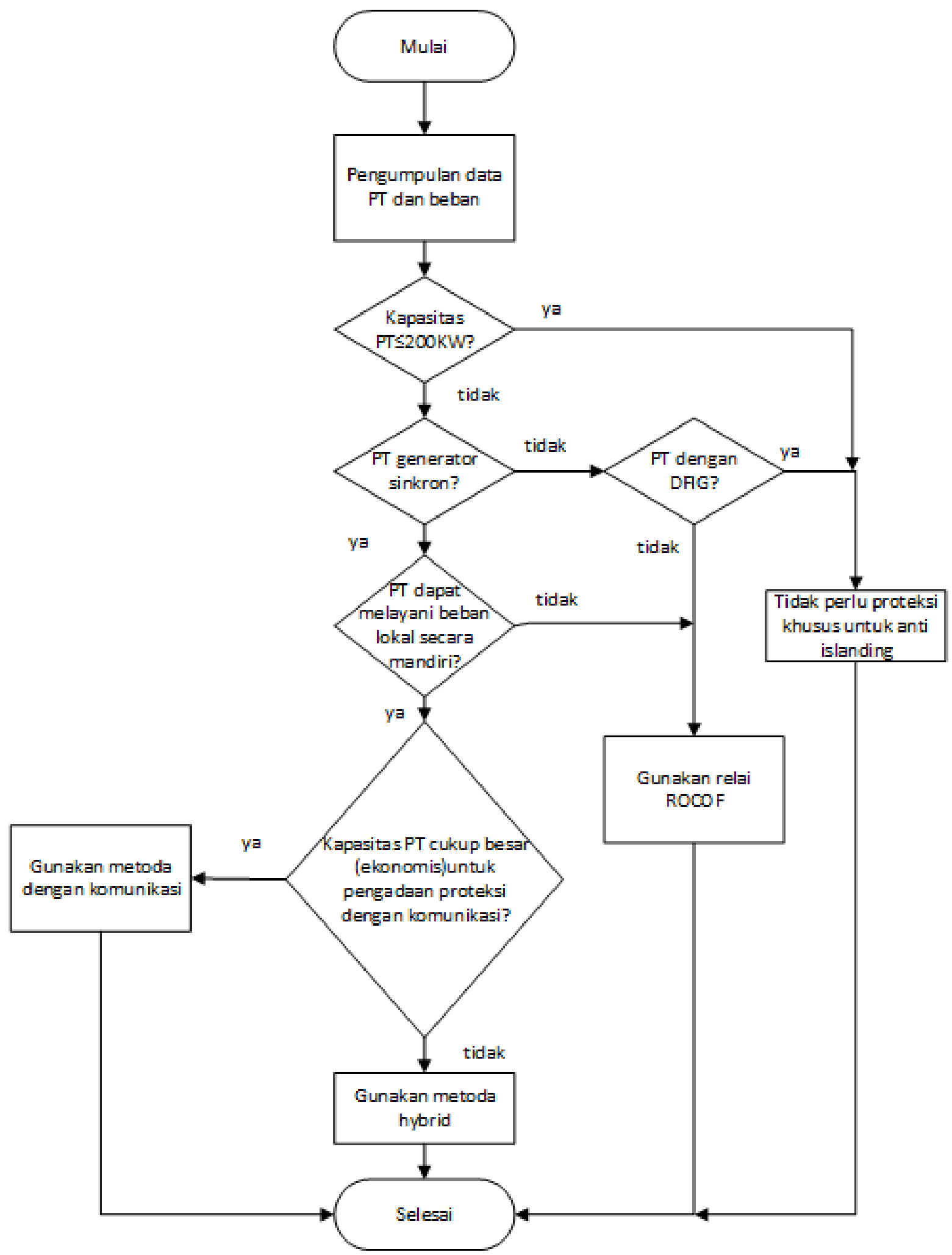

Gambar 6. Flowchart metoda pemilihan relai anti islanding 


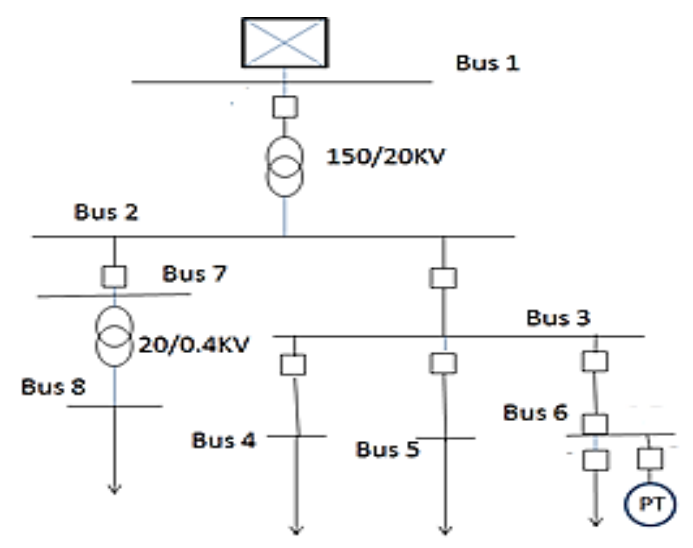

Gambar 7. Jaringan distribusi dengan sebuah PT [10]

Dari Gambar 8, terlihat keluaran PT berpotongan dengan kurva beban sebanyak dua kali dalam satu hari. Yaitu saat sebelum dan sesudah waktu beban puncak. Jika perbedaan antara daya beban dan keluaran PT cukup kecil, relai metoda pasif dapat gagal mendeteksi kondisi islanding. Lama islanding tidak terdeteksi (zona tak terdetaksi) adalah $\Delta \mathrm{t}_{1}$ dan $\Delta \mathrm{t}_{2}$, yaitu durasi dimana ketidakseimbangan daya mencapai 10\% keluaran PT. Nilai titik-titik waktu dimana terjadi perpotongan kurva keluaran $110 \%$ dan $90 \%$ PT dengan kurva beban dihitung dengan metoda interpolasi menggunakan software Microsoft Excell. Hasil perhitungan ditunjukkan pada Tabel 2 .

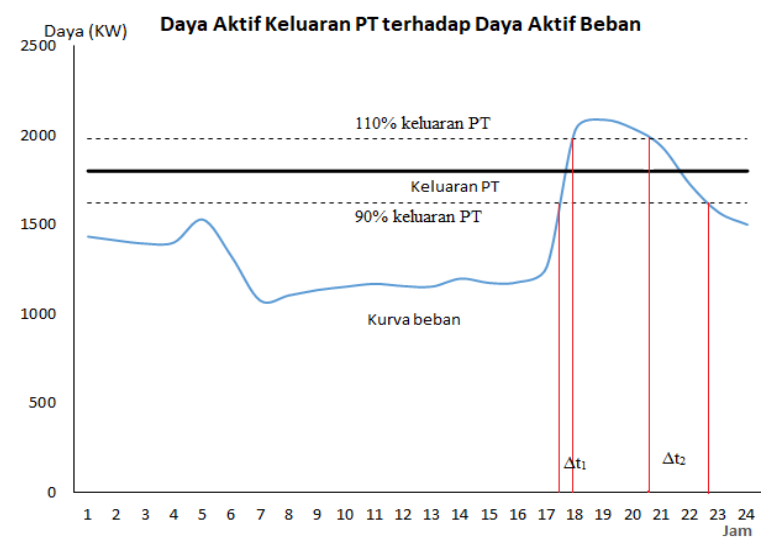

Gambar 8. Kurva daya aktif beban dan keluaran daya aktif PT

Dari Tabel 2, terlihat bahwa durasi islanding tidak dapat dideteksi oleh relai cukup lama, yaitu 28,12 menit dan 124,69 menit. Jauh lebih besar dari angka 1,7 detik yang didasarkan pada aturan
PLN.

Tabel 2. Lama Waktu Ketidakseimbangan Daya Aktif Keluaran PT terhadap Beban $\leq 10 \%$

\begin{tabular}{|c|c|}
\hline & Waktu (menit) \\
\hline$\Delta \mathbf{t}_{\mathbf{1}}$ & 28,12 \\
\hline $\boldsymbol{\Delta} \mathbf{t}_{\mathbf{2}}$ & 124,69 \\
\hline
\end{tabular}

Sensitifitas relai ROCOF tidak hanya ditentukan oleh ketidakseimbangan daya aktif, tetapi juga ketidakseimbangan daya reaktif. Walaupun saat grid terlepas daya aktif PT seimbang dengan daya aktif beban, tetapi daya reaktifnya tidak, maka perubahan frekuensi tetap akan terjadi. Demikian pula sebaliknya. Karena kurva keluaran daya reaktif PT perlu dibandingkan dengan kurva kebutuhan daya reaktif jaringan, maka kurva daya reaktif perlu diplot, seperti terlihat pada Gambar 9.

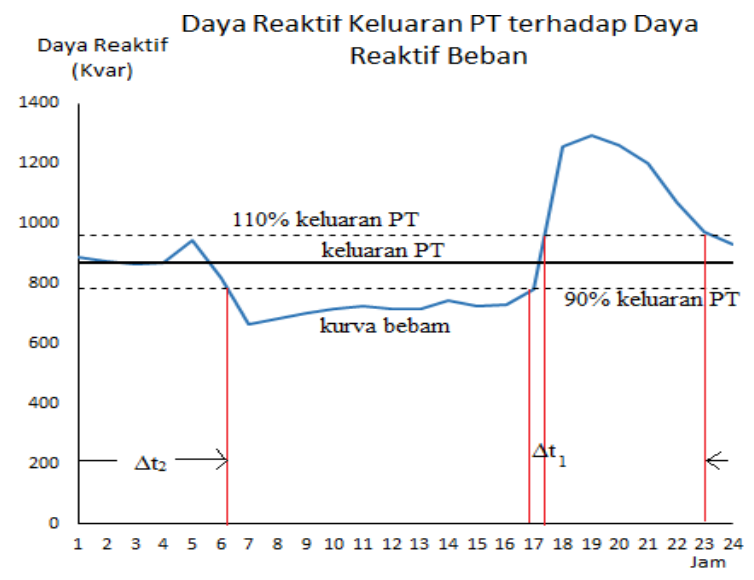

Gambar 9. Kurva daya reaktif beban dan keluaran daya reaktif PT.

Pada Gambar 9, ketidakseimbangan daya $\leq$ $10 \%$ (zona tak terdeteksi) berdurasi $\Delta \mathrm{t}_{1}$ dan $\Delta \mathrm{t}_{2}$. Zona tak terdeteksi karena keseimbangan daya reaktif $\Delta \mathrm{t}_{1}$ terjadi dalam waktu yang hampir bersamaan dengan zona tak terdeteksi daya aktif (Gambar 8) yaitu sekitar pukul 17. Sedangkan $\Delta \mathrm{t}_{2}$ terjadi pada waktu yang berbeda. Pada kurva daya aktif (Gambar 8), $\Delta \mathrm{t}_{2}$ terjadi antara pukul 20 lebih sampai pukul 22 lebih, sedangkan pada kurva daya reaktif (Gambar 9) pada pukul 23 sampai pukul 6 lebih. Saat terjadi islanding karena kesetimbangan daya aktif pada waktu $\Delta \mathrm{t}_{2}$ pada Gambar 8, daya reaktif tidak cukup setimbang. Permintaan beban akan daya reaktif jauh lebih besar dari pada keluaran PT (gambar 
9), sehingga kondisi islanding tidak akan bertahan tanpa terdeteksi.

Untuk mengklarifikasi apakah keseimbangan daya aktif $\Delta \mathrm{t}_{1}$ terjadi pada waktu yang bersamaan dengan waktu terjadinya keseimbangan daya reaktif, maka perlu dilakukan intrapolasi waktu kejadian dengan menggunakan Microsoft Excell. Hasil interpolasi diperlihatkan pada Table 3 .

Tabel 3. Waktu Terjadinya Ketidakseimbangan Daya Aktif Keluaran PT terhadap Beban $\leq 10 \%$

\begin{tabular}{|c|c|c|}
\hline Daya & $\begin{array}{c}\text { Mulai } \\
\text { (jam:menit:detik) }\end{array}$ & $\begin{array}{c}\text { Berakhir } \\
\text { (jam:menit:detik) }\end{array}$ \\
\hline Aktif & $17: 27: 54$ & $17: 55: 59$ \\
\hline Reaktif & $17: 00: 00$ & $17: 22: 33$ \\
\hline
\end{tabular}

Dari data pada Tabel 3, terlihat zona tak terdeteksi untuk daya aktif terjadi setelah zona tak terdeteksi daya reaktif telah berakhir. Sehingga saat dimana zona tak terdeteksi untuk daya aktif bersamaan dengan zona tak terdeteksi daya reaktif tidak terjadi. Akibatnya relai ROCOF akan selalu berhasil mendeteksi kondisi islanding. Jadi untuk PT dalam kasus ini, relai ROCOF dapat digunakan untuk mendeteksi kondisi islanding.

\section{KESIMPULAN}

Sebuah metoda pemilihan relai anti islanding bagi pembangkit tersebar telah diusulkan. Pemilihan relai didasarkan kepada kapasitas pembangkit, teknologi pembangkitan yang digunakan dan sisi ekonomis relai terhadap kapasitas PT. Metoda juga didasarkan pada persyaratan proteksi anti islanding yang diterapkan dalam peraturan PLN. Dari contoh aplikasi metoda, terlihat bahwa metoda sudah berhasil memilih relai yang sesuai bagi sebuah PT bergenerator sinkron. Pada penelitian selanjutnya akan dibahas pemilihan setting relai yang tidak hanya menitikberatkan pada sensitifitas relai tetapi juga stabilitas relai terhadap kejadian bukan islanding yang mengubah parameter di jaringan.

\section{UCAPAN TERIMA KASIH}

Penelitian ini didanai dalam kegiatan penelitian dosen Jurusan Teknik Elektro Fakultas Teknik,
Universitas Andalas No.

105/UN.16.09.D/PL/2017

\section{DAFTAR PUSTAKA}

[1] A. M. Massoud, K. H. Ahmed, S. J. Finney, and B. W. Williams, "Harmonic distortion-based island detection technique for inverter-based distributed generation," IET Renewable Power Generation, vol. 3, pp. 493-507, 2009.

[2] Pedoman Penyambungan Pembangkit Listrik Energi Terbarukan ke Sistem Distribusi PLN, PT. PLN, 2014.

[3] A. Dysko, A. MacKay, and G. Burt, "Neutral Voltage Displacement Protection Requirement for DG," University of Strathclyde, Glasgow 2010.

[4] University of Strathclyde, "Recommendations for Setting of Loss of Mains Protection Relays," Energy Networks Association, London 2009.

[5] A. Dysko, I. Abdulhadi, X. Li, and C. Booth, "Assessment of Risk Resulting from the Adjustment of ROCOF Based Loss of Mains Protection Settings, Phase I " University of Strathclyde, Glasgow 2013.

[6] N. Jenkins, R. Allan, P. Crossley, D. Kirschen, and G. Strbac, Embedded Generation vol. 31. London: The Institution of Engineering and Technology, 2008.

[7] W. Freitas, X. Wilsun, C. M. Affonso, and H. Zhenyu, "Comparative analysis between ROCOF and vector surge relays for distributed generation applications," IEEE Transactions on Power Delivery, vol. 20, pp. 1315-1324, 2005.

[8] P. Mahat, Z. Chen, and B. Bak-Jensen, "A hybrid islanding detection technique using average rate of voltage change and real power shift," IEEE Transactions on Power Delivery, vol. 24, pp. 764-771, 2009.

[9] S. P. Chowdhury, S. Chowdhury, T. Chui Fen, and P. A. Crossley, "Islanding protection of distribution systems with distributed generators - A comprehensive survey report," in 2008 IEEE Power and Energy Society General Meeting Conversion and Delivery of Electrical 
Energy in the 21st Century, Pittsburgh, 2008, pp. 1-8.

[10] Adrianti and N. Mukhlisiah, "Rekonfigurasi Relai Proteksi Setelah Penambahan Pembangkit Tersebar pada Jaringan Distribusi," Jurnal Nasional Teknik Elektro, vol. 6, Juli 2017.

[11] D. A. Sari, "Peramalan Kebutuhan Beban Jangka Pendek Menggunakan Jaringan Syaraf Tiruan Backpropagation," S1, Teknik Elektro, Universitas Diponegoro, Semarang, 2006.

\section{Biodata Penulis}

Adrianti, menyelesaikan pendidikan S1 dan S2 di Universitas Sriwijaya dan Institut Teknologi Bandung. S3 diselesaikannya tahun 2015 di University of Strathclyde, Glasgow, Inggris. Saat ini bekerja sebagai dosen di jurusan Teknik Elektro, Universitas Andalas. Minat penelitiannya adalah proteksi sistem tenaga, keandalan sistem tenaga, pembangkit tersebar dan analisa gangguan. 